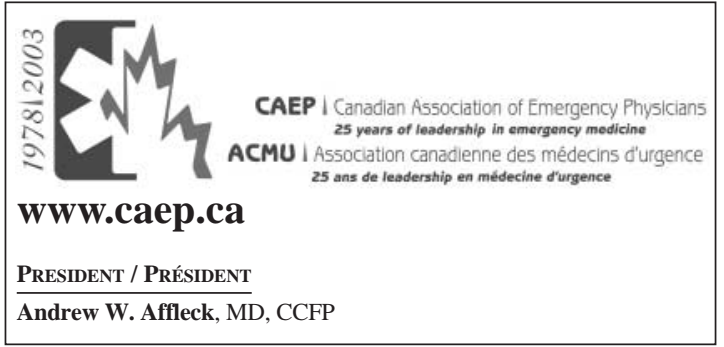

Canadian Journal of Emergency Medicine

Journal canadien de la médecine d'urgence

EDITOR-IN-CHIEF / RÉDACTEUR EN CHEF

Grant Innes, MD
University of British Columbia, Vancouver @caep.ca

SENIOR Associate Editor / RÉdacteur ADJOINT

James Ducharme, MD Jim_ducharme@bigfoot.com

Dalhousie University, Saint John, NB

MANAGING EDITOR / RÉDACTRICE ADMINISTRATIVE

Heidi Innes, BSc, BEd cjem@caep.ca

ASSOCIATE EdITORS / RÉDACTEURS ASSOCIÉS

EM ADVANCES (original research)

Jacques S. Lee, MD, University of Toronto, Toronto

Ian G. Stiell, MD, MSc, University of Ottawa, Ottawa

Christian Vaillancourt, MD, MSc, University of Ottawa, Ottawa

CJEM Journal CLUB

Michael J. Bullard, MD, University of Alberta, Edmonton

CASE REPORTS

Anthony S. Taylor, MD, University of Calgary, Calgary

SMall URban and RuRal Issues

James M. Thompson, MD, Dalhousie University, Charlottetown

Methodology: THE SCIENCE of EM

Riyad B. Abu-Laban, MD, MHSc, University of British Columbia, Vancouver

PHARMACOTHERAPY

Peter J. Zed, BSc(Pharm), PharmD, University of British Columbia, Vancouver

Jeff Eppler, MD, Kelowna General Hospital, Kelowna, BC

ED ADMINISTRATION

Jeremy M. Etherington, MD, St. Paul's Hospital, Vancouver

EDUCATION

Jason R. Frank, MD, MA (Ed), University of Ottawa, Ottawa

STATE OF THE ART (review articles and topical updates)

Vacant

TOXICOLOGY

Roy Purssell, MD, University of British Columbia, Vancouver

CONTROVERSIES (issues and commentaries)

Jeffrey Freeman, MD, University of Michigan, Ann Arbor, Mich.

Pediatric EM

Ran Goldman, MD, Hospital for Sick Children, Toronto

Niranjan Kissoon, MD, University of Florida HSC/Jacksonville, Jacksonville, Fla.

HuMOUR AND HUMANITY

Virginia Robinson, MD, Fernie District Hospital, Fernie, BC

Diagnostic Challenge

Robert McGraw, MD, Queen's University, Kingston, Ont.

INTERNATIONAL EM

Garth Dickinson, MD, Christ Church, Barbados

Medical Mythology

Mel Herbert, MD, University of Southern California, Los Angeles

RESIDENT ISSUES

Cameron MacGougan, MD, University of Alberta, Edmonton

Paul Tourigny, MD, Queen's University, Kingston, Ont.
CJEM

Journal canadien de la médecine d'urgence

Canadian Journal of Emergency Medicine

$J C M U$

Vol. 6, No. 6, November / novembre 2004

\section{TABLE OF CONTENTS • TABLE DES MATIÈRES}

LetTers • Courrier

395

ED overcrowding, J. Ryan. ESI and CTAS, J. Fan, S. Upadhye, K. Woolfrey.

Pediatric EM • Pédiatrie d'urgence

Pediatric wrist buckle fractures: Should we just splint and go?

A.C. Plint, J.J. Perry, J.L.Y. Tsang

\section{EM Advances • Innovations en MU}

Lack of consensus on corneal abrasion management: results of a national survey

L. Calder, S. Balasubramanian, I. Stiell

Focused abdominal ultrasound for blunt trauma in an emergency department without advanced imaging or on-site surgical capability M. Shuster, R.B. Abu-Laban, J. Boyd, C. Gauthier, S. Mergler,

L. Shepherd, C. Turner

Laryngoscopic views during rapid sequence intubation

in the emergency department

C.A. Graham, A.J. Oglesby, D. Beard, D.W. McKeown

ED AdMinistration • L'ADMINISTRATION DE LA MU

Revisions to the Canadian Emergency Department Triage and Acuity Scale Implementation Guidelines

M. Murray, M. Bullard, E. Grafstein; for the CTAS and CEDIS

National Working Groups

Pediatric EM • Pédiatrie d'urgence

Cardiac concussion (commotio cordis)

R. Valani, A. Mikrogianakis, R.D. Goldman

COMmEnTARY • COMMENTAIRE

Mandating automated external defibrillators in schools: Fire, ready, aim!

L. Brown

Pediatric EM • Pédiatrie d'urgence

The removal of coins from the upper esophageal tract of children by emergency physicians: a pilot study

E.J. Vargas, A.P. Mody, T.Y. Kim, T.K. Denmark, J.A. Moynihan, B.B. Barcega, A. Khan, R.T. Clark, L. Brown

CJeM Journal Club • Club de lecture JCMU

Do femoral nerve blocks improve acute pain control in adults with isolated hip fractures? K. Hurley

Medical Mythology • Mythes médicaux

Pyloric stenosis. J.E. Colletti 
EdITORS AT LARGE / RÉDACTEURS OCCASIONNELS

Tim Allen, MD, Quebec City

Lance Brown, MD, MPH, FACEP, Loma Linda, Calif.

Jeffrey R. Brubacher, MD, Vancouver

Greta Cummings, BScN, MEd, RN, PhD, Edmonton

Brian Goldman, MD, MCFP (EM), Toronto

Daniel W. Howes, MD, FRCPC, Kingston, Ont.

Shane Neilson, BSc, MD, Halifax

Michael J. Schull, MD, MSc, Toronto

Marco Sivilotti, MD, MSc, Kingston, Ont.

Andrew H. Travers, BSc, MD, MSc (Epidemiol), Halifax

Andrew Worster, MD, MSc, Hamilton, Ont

\section{Web Site}

Jim Squires, MD

Guelph General Hospital, Guelph, Ont.

Business ANd Promotion

Chris Evans, MD

University of Alberta, Edmonton jsquires2504@ rogers.com

Translation / Traduction

Danielle Séguin-Tétreault, MTrad

Marketing And Advertising SALEs / Marketing et publicité

Keith Health Care info@keithhealthcare.com

Toronto: 905 278-6700 or 800 661-5004; fax 905 278-4850

Montréal: 514 624-6979 or 877 761-0447; fax 514 624-6707

CJEM is owned by the Canadian Association of Emergency Physicians (CAEP) and printed by Dollco Printing, Ottawa.

CAEP Head Office: 1785 Alta Vista Dr., Ste. 104, Ottawa ON

K1G 3Y6; tel 613 523-3343; fax 613 523-0190; cjem@caep.ca

Editorial inquiries, submissions and all other correspondence: CJEM, c/o Dr. Grant Innes, Dept. of Emergency Medicine, St. Paul's Hospital, 1081 Burrard St., Vancouver BC V6Z 1Y6; 604 806-8980, fax 604 608-9810, cjem@caep.ca

Instructions for Authors, Service Information: see Table of Contents. Address changes or requests for permission to reproduce items in CJEM: contact Susan Norrington at the CAEP Head Office.

Publications mail agreement no. 0344505499. Return undeliverable Canadian copies to the CAEP Head Office. USPS \#017-766 USPS periodical postage paid at Champlain, NY. Return other undeliverable copies to IMS of NY, 100 Walnut St., \#1, PO Box 1518 Champlain NY 12919-1518. ISSN 1481-8035.

We acknowledge the financial support of the Government of Canada, through the Canada Magazine Fund, toward our editorial costs.

\section{PAAB* Canadä}

All prescription drug advertisements have been cleared by the Pharmaceutical Advertising Advisory Board.

(C) 2004 Canadian Association of Emergency Physicians

Association canadienne des médecins d'urgence

Publisher / Éditeur

CJEM is published in January, March, May, July, September and November for CAEP by the Canadian Medical Association, Ottawa. CAEP and the CMA assume no responsibility or liability for damages arising from any error or omission, or from the use of any information or advice contained in the journal, including articles, editorials, case reports, reviews, media reviews, letters and advertisements. All editorial matter in CJEM represent the opinions of the authors and not necessarily those of CAEP or the CMA. President, CMA Publications / Président, Publications de L'AMC Graham Morris

Associate Director, Publishing Services

DiRECTRICE ASSOCIÉE, SERVICES D'ÉDITION

Glenda Proctor, MSc, ELS

Editor / RÉDACTRICE, Publications

Jennifer E. Raiche

800 663-7336 x2114; fax 613 565-2382; jennifer.raiche@ cma.ca

PRODUCTION

Kathryn A. Freamo

Nicole Barbeau, Clara Walker

Classified Advertising / AnNonces Classées

Beverley Kirkpatrick, Deborah Rodd, Tracy Huckabone

613 731-8610 x2127/2314; fax 613 565-7488; advertising@cma.ca

DisPlay ADVERTISING / ANNONCES PUBLICITAIRES

Nancy Pope, 613 731-8610 x2111
Diagnostic Challenge • Défi diagnostique

Go to bed, sleepy head; Answer. P.G. Katis

446; 451

Humour and Humanity • Humour et Humanité

Finding balance. M.J. Thorne

NeWS • Nouvelles

CAEP Annual Scientific Assembly, May 28-June 1, 2005:

Call for Abstracts • Assemblée scientifique annuelle de l'ACMU.

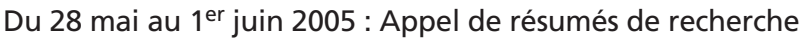

Peer Reviewers • Réviseurs

Calendar $\bullet$ Calendrier

CJEM SUBJECT INDEX • INDEX DES SUJETS DU JCMU

CJEM AUTHOR INDEX • INDEX DES AUTEURS DU JCMU

Classified Advertising • AnNonces ClAssées

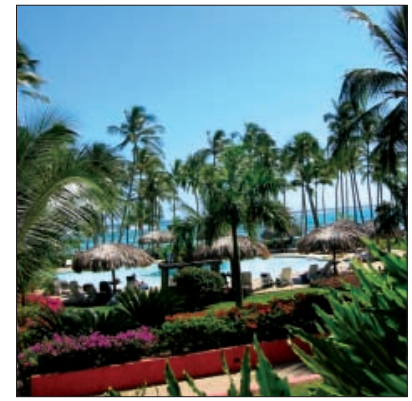

About the Cover:

What does this cover photo have to do with Canadian EM? Punta Cana, in the Dominican Republic, was the site of CAEP's 2004 "CME in the SUN" course. Join us in Punta Cana, Jan. 28-Feb. 5, for our 2005 "CME in the SUN." Photo highlights the Club Med Resort, beach, pool and gardens.

Photo by: Vera Klein, CAEP Head Office 